\title{
Impact of COVID-19 in Immunosuppressed Children With Neuroimmunologic Disorders
}

Gemma Olivé-Cirera, MD, Elianet Fonseca, MD, Verónica Cantarín-Extremera, MD, María Vázquez-López, MD, María Jiménez-Legido, MD, Verónica González-Álvarez, MD, Juliana Ribeiro-Constante, MD,

Ana Camacho-Salas, MD, Itxaso Martí, MD, Ramon Cancho-Candela, MD, María Jesús Martínez-González, MD, Albert Saiz, MD, PhD, and Thaís Armangué, MD, PhD, on behalf of the Spanish Study Group NeuroimmunoPed-Covid

Neurol Neuroimmunol Neuroinflamm 2022;9:e1101. doi:10.1212/NXI.0000000000001101

\section{Abstract}

\section{Background and Objectives}

To investigate whether children receiving immunosuppressive therapies for neuroimmunologic disorders had (1) increased susceptibility to SARS-CoV2 infection or to develop more severe forms of COVID-19; (2) increased relapses or autoimmune complications if infected; and (3) changes in health care delivery during the pandemic.

\section{Methods}

Patients with and without immunosuppressive treatment were recruited to participate in a retrospective survey evaluating the period from March 14, 2020, to March 30, 2021. Demographics, clinical features, type of immunosuppressive treatment, suspected or confirmed COVID-19 in the patients or cohabitants, and changes in care delivery were recorded.

\section{Results}

One hundred fifty-three children were included: 84 (55\%) female, median age 13 years (interquartile range [8-16] years), 79 (52\%) on immunosuppressive treatment. COVID-19 was suspected or confirmed in 17 (11\%) (all mild), with a frequency similar in patients with and without immunosuppressive treatment $(11 / 79$ [14\%] vs $6 / 74[8 \%], p=0.3085)$. The frequency of neurologic relapses was similar in patients with (18\%) and without (21\%) COVID19. Factors associated with COVID-19 included having cohabitants with COVID-19 ( $p<$ $0.001)$ and lower blood levels of vitamin $\mathrm{D}(p=0.039)$. Return to face-to-face schooling or mask type did not influence the risk of infection, although $43(28 \%)$ children had contact with a classmate with COVID-19. Clinic visits changed from face to face to remote for 120 (79\%) patients; 110 (92\%) were satisfied with the change.

\section{Discussion}

In this cohort of children with neuroimmunologic disorders, the frequency of COVID-19 was low and not affected by immunosuppressive therapies. The main risk factors for developing COVID-19 were having cohabitants with COVID-19 and low vitamin D levels.

\author{
Correspondence \\ Dr. Armangué \\ armangue@clinic.cat
}

\section{MORE ONLINE}

\section{COVID-19 Resources}

For the latest articles, invited commentaries, and blogs from physicians around the world

NPub.org/COVID19

\section{(c) Infographic}

http://links.lww.com/NXI/ A671

From the Pediatric Neuroimmunology Program (G.O.-C.,E.F.,A.S.,T.A.), Institut d'Investigacions Biomèdiques August Pi i Sunyer (IDIBAPS)-Hospital Clinic, University of Barcelona; Pediatric Neurology Unit of Parc Taulí Hospital of Sabadell (G.O.-C.), Barcelona; Pediatric Neurology Unit of Hospital Infantil Universitario Niño Jesús (V.C.-E.,M.J.-L.), Madrid; Pediatric Neurology Unit of Hospital Gregorio Marañón (M.V.-L.), Madrid; Pediatric Neuroimmunology Unit (V.G.-A.J.R.-C.,T.A.), Neurology Service, Sant Joan de Déu (SJD) Children's Hospital, University of Barcelona; Pediatric Neurology Unit of Hospital Universitario 12 de Octubre, Complutense University of Madrid (A.C.S.); Pediatric Neurology Unit of Hospital Universitario Donostia (I.M.), Guipuzcoa; Pediatric Neurology Unit of Hospital Universitario Río Hortega (R.C.-C.), Valladolid; and Pediatric Neurology Unit of Cruces University Hospital (M.J.M.-G.), Bilbao, Spain.

Go to Neurology.org/NN for full disclosures. Funding information is provided at the end of the article.

Spanish Study Group NeuroimmunoPed-Covid coinvestigators are listed in the appendix at the end of the article.

The Article Processing Charge was funded by Instituto Salud Carlos III-FEDER.

This is an open access article distributed under the terms of the Creative Commons Attribution-NonCommercial-NoDerivatives License 4.0 (CC BY-NC-ND), which permits downloading and sharing the work provided it is properly cited. The work cannot be changed in any way or used commercially without permission from the journal. 


\section{Glossary}

IVIg = IV immunoglobulin; MS = multiple sclerosis; PIMS = pediatric inflammatory multisystem syndrome.

Pediatric multiple sclerosis (MS), relapsing myelin oligodendrocyte glycoprotein-associated diseases, and other chronic inflammatory neuroimmunologic diseases are frequently treated with immunosuppressants, which may decrease the cellular and humoral immunologic responses against viruses and other infectious agents. Thus, these children may be at increased risk for SARS-CoV-2 infection or to develop severe COVID-19. ${ }^{1,2}$ Furthermore, it is unclear whether COVID-19 infection in these children increases the risk for having neurologic relapses or development of COVID-19-associated pediatric inflammatory multisystem syndrome (PIMS). ${ }^{1}$

These concerns and the lack of consensus guidelines led scientific societies to provide different and sometimes contradictory recommendations for school attendance and patient management. In addition, many hospitals opted for remote rather than face-to-face medical visits. However, there are no epidemiologic studies to assess whether this group of patients has in fact an increased susceptibility to develop COVID-19 or have poorer outcomes if they do. Furthermore, the consequences of the measures adopted to prevent SARS-CoV-2 infection in these children have not been evaluated.

Therefore, we conducted a study to investigate whether children receiving immunosuppressive therapies due to neuroimmunologic diseases had (1) increased susceptibility to SARS-CoV2 infection or to develop more severe forms of COVID-19; (2) increased relapses or inflammatory complications if infected; and (3) changes in health care delivery during the pandemic. This information will allow us to make more informed management decisions for these patients.

\section{Methods}

For this retrospective observational multicenter study, an invitation to participate was sent to pediatric neurologists in Spain through the Spanish Pediatric Neurology Society that includes the Neuroimmunology and Infectious Diseases of CNS Study Group. To rule out bias due to regional differences in COVID-19 incidence and the preventive measures instituted by local governments, control individuals were consecutively recruited at each regional center as follows: for each patient enrolled who was receiving immunosuppressants, the next child seen in the clinic who was close in age and had a neuroinflammatory disease but was not receiving immunosuppressants was invited to participate in the study. If this first control subject declined, the next consecutive potential control subject was recruited (eTable 1, links.lww. com/NXI/A654). We defined immunosuppressive treatment as any chronic treatment that impairs innate or adaptive immunity and therefore may confer a higher risk for infectious diseases. For the controls not receiving immunosuppressive treatment, immunomodulatory drugs were allowed (e.g., interferon beta-1a, acetate glatiramer, or IV immunoglobulins [IVIgs]) as these agents do not confer an increased susceptibility for infections.

Each treating physician administered an initial questionnaire between July 1, 2020, and August 31, 2020, that corresponded to the first wave of the pandemic and home lockdown in Spain (March 14, 2020-June 21, 2020). This was followed by a second questionnaire administered during the interval period from April 1, 2021, to April 30, 2021, after the second and third waves of the pandemic when face-to-face school attendance was allowed (June 22, 2021-March 31, 2021).

The questionnaires were divided into 6 sections: (1) epidemiologic data regarding age, sex, hospital, and geographical area; (2) baseline neuroimmunologic disease, presence or absence of active immunosuppressive treatment and/or side effects, and oral supplementation of vitamin D; (3) worsening or development of neurologic disease relapses during the study period; (4) symptoms suggestive of SARS-CoV-2 infection during the study period and confirmatory microbiological tests (PCR and/or antigen test); (5) exposure to possible sources of infection (e.g., suggestive symptoms in cohabitants, cohabitants working outside the home during the lockdown [e.g., essential workers], other risk factors for severe infection in cohabitants, return to face-to-face schooling, type of mask used, and history of classroom mates positive for COVID19 ); and (6) change in provision of medical care and satisfaction with these changes. Physicians completed the surveys and also provided the levels of vitamin D $(25-\mathrm{OH}-$ D3) in blood when this information was available.

During the first period of the study, testing for SARS-CoV-2 in Spain was limited mainly to hospitalized patients, and therefore, many people with mild symptoms or who were asymptomatic after an exposure were not tested. Thus, for this period, we considered that COVID-19 was confirmed if patients had a positive PCR or antigen test and was suspected if patients only had symptoms noted. For the second period, the capacity of SARS-CoV-2 testing in Spain was higher, and only confirmed cases were included.

\section{Standard Protocol Approvals, Registrations, and Patient Consents}

The study was approved by the Ethics Committee at Sant Joan de Déu Children's Hospital, Esplugues de Llobregat, Barcelona, Spain (CODE PIC-126-20). All participants were fully informed about study requirements and accepted data sharing and privacy policy before participating in the study. 
Table 1 Risk Factors for COVID-19

\begin{tabular}{|c|c|c|c|c|}
\hline & \multirow{2}{*}{$\frac{\text { All }}{N=153}$} & \multicolumn{2}{|c|}{ COVID-19 infection } & \multirow[b]{2}{*}{$p$ Value $^{a}$} \\
\hline & & Yes $(n=17)$ & No $(n=136)$ & \\
\hline Age, in yr, median (IQR) & $13(8-16)$ & $11(6-13)$ & $13(8-16)$ & 0.9155 \\
\hline Female sex & $84(55 \%)$ & $10(59 \%)$ & $62(54 \%)$ & 0.8003 \\
\hline Immunosuppressive treatment & $79(52 \%)$ & $11(65 \%)$ & $68(50 \%)$ & 0.3085 \\
\hline Cohabitant infection & $29(19 \%)$ & $13(76 \%)$ & $16(12 \%)$ & $<0.001$ \\
\hline Cohabitating with essential workers & $73(48 \%)$ & $8(47 \%)$ & $65(48 \%)$ & 1 \\
\hline \multicolumn{5}{|l|}{ Vitamin D (25(OH)D3) } \\
\hline Oral supplementation & $57(37 \%)$ & $8(47 \%)$ & $49(36 \%)$ & 0.4293 \\
\hline Blood levels, ${ }^{\mathrm{b}}$ in ng/dL, median (IQR) & $28(22-39)$ & $20(16-29)$ & $29(23-39)$ & 0.03935 \\
\hline Reinitiation of face-to-face school ${ }^{\mathrm{c}}$ & $133(87 \%)$ & $15(88 \%)$ & $118(87 \%)$ & 0.3901 \\
\hline Classmate infection & $43(28 \%)$ & $5(29 \%)$ & $38(28 \%)$ & 1 \\
\hline Use of daily protective mask & $144(94 \%)$ & $15(88 \%)$ & $129(95 \%)$ & 0.2624 \\
\hline Type of mask & & & & 0.1071 \\
\hline FFP2 & $34(22 \%)$ & $1(6 \%)$ & $33(24 \%)$ & \\
\hline Surgical & 78 (51\%) & $12(70 \%)$ & $66(49 \%)$ & \\
\hline Cloth & $32(21 \%)$ & $2(12 \%)$ & $30(22 \%)$ & \\
\hline None & $9(6 \%)$ & $2(12 \%)$ & $7(5 \%)$ & \\
\hline
\end{tabular}

Abbreviation: IQR = interquartile range.

${ }^{a}$ Fisher exact test.

${ }^{\mathrm{b}} \mathrm{N}=110$ (62 with immunosuppressants and 48 without). Differences of vitamin D levels between groups were more obvious when evaluating only confirmed COVID-19 cases (median $17 \mathrm{ng} / \mathrm{dL}$ [IQR 14-19 ng/dL] vs median $29 \mathrm{ng} / \mathrm{dL}$ [IQR 23-39 ng/dL], $p=0.0063$ ).

c Full-time face-to-face or mixed remote face-to-face school format.

\section{Data Availability}

The data presented in this study are available on request from the corresponding author. The data are not publicly because dissemination has not been explicitly foreseen by the local ethics committee.

\section{Statistical Analyses}

Data are represented as number and percentage for categorical variables or median and interquartile range (IQR) for continuous variables. Comparisons of dichotomous variables between patients with and without immunosuppressive treatment were analyzed using the Fisher exact test. Continuous variables were analyzed using the Wilcoxon rank-sum test. Level of significance was established at the 2 -sided $5 \%$ level. Analyses were performed using R version 3.6 .3 (202002-29) program.

\section{Results}

A total of 153 children ( 84 [55\%] female) with a median age of 13 years (IQR 8-16 years) from 12 clinics/centers were included in the study. The neuroimmunologic disorders of patients included in the study are listed in eTable 1 (links.lww. com/NXI/A654). Seventy-nine patients (52\%) were receiving immunosuppressant therapy, and $74(48 \%)$ were untreated (64) or treated with immunomodulatory therapy. No differences in demographic features were noted between the 2 groups (eTable 1, links.lww.com/NXI/A654).

The potential risks factors for COVID-19 infection and the distribution of patients who developed COVID-19 according to these risk factors are shown in Table 1 . The frequency of immunosuppressive treatment was similar in patients who developed suspected or confirmed COVID-19 and patients who did not develop the infection $(11 / 17,65 \%$ vs $68 / 136,50 \%, p=$ 0.3085). Overall, this represents that the frequency of COVID19 infection was similar in patients with and without immunosuppressive treatment $(11 / 79[14 \%]$ vs $6 / 74[8 \%], p=0.3085)$.

Among the 79 patients receiving immunosuppressive therapies, 36 showed evidence of lymphopenia and/or B-cell depletion in blood tests, and the other 43 that did not have these alterations. The absence of association between immunosuppression and development of COVID-19 was also observed when only the 36 patients with lymphopenia and/or B-cell depletion were compared with the 74 patients who did not receive immunosuppressants $(3 / 36$ vs $6 / 74, p=1)$. Of these 36 patients, $23(64 \%)$ had complete B-cell suppression 
Table 2 Diagnostic and Clinical Features of Patients With Suggestive COVID-19

\begin{tabular}{|c|c|c|c|c|c|c|c|c|}
\hline Case & $\begin{array}{l}\text { 1st or } 2 \text { nd } \\
\text { period, }{ }^{,} \text {month-year } \\
\text { of infection }\end{array}$ & $\begin{array}{l}\text { Underlying } \\
\text { neurologic } \\
\text { disorder }\end{array}$ & $\begin{array}{l}\text { Active } \\
\text { immunosuppressive } \\
\text { treatment }\end{array}$ & $\begin{array}{l}\text { Relapse of } \\
\text { underlying } \\
\text { neurologic } \\
\text { disorder }\end{array}$ & $\begin{array}{l}\text { COVID-19 } \\
\text { symptoms }\end{array}$ & $\begin{array}{l}\text { Severity of } \\
\text { COVID-19 } \\
\text { infection }\end{array}$ & $\begin{array}{l}\text { SARS-CoV-2- } \\
\text { PCR } \\
\text { confirmation }\end{array}$ & $\begin{array}{l}\text { SARS-CoV- } \\
\text { 2-specific } \\
\text { treatment }\end{array}$ \\
\hline 1 & 1st, March 2020 & MOGAD & $\begin{array}{l}\text { Yes (rituximab and IVIg } \\
\text { replacement) }\end{array}$ & Yes & URTI and fever & Mild & No & None \\
\hline 2 & 1st, March 2020 & $\begin{array}{l}\text { Rasmussen } \\
\text { encephalitis }\end{array}$ & No & No & $\begin{array}{l}\text { URTI and } \\
\text { headache }\end{array}$ & Mild & No & None \\
\hline 3 & 1st, March 2020 & Neuroinfection & No & Yes & URTI and fever & Mild & No & None \\
\hline 4 & 1st, March 2020 & OMS & $\begin{array}{l}\text { Yes (monthly steroids and } \\
\text { IVIg) }\end{array}$ & Yes & URTI and fever & Mild $^{b}$ & Yes & None \\
\hline 5 & 1st, March 2020 & $\mathrm{IIH}$ and $\mathrm{AlJ}$ & Yes (tocilizumab) & No & URTI & Mild & Yes & None \\
\hline 6 & 1st, April 2020 & MS & No & No & URTI and fever & Mild & No & None \\
\hline 7 & 1st, April 2020 & $A C h R+M G$ & Yes (steroids + azathioprine) & No & $\begin{array}{l}\text { URTI, fever, and } \\
\text { headache }\end{array}$ & Mild & No & None \\
\hline 8 & 1st, May 2020 & MS & Yes (fingolimod) & No & URTI & Mild & No & None \\
\hline 9 & 2nd, August 2020 & $\begin{array}{l}\text { Rasmussen } \\
\text { encephalitis }\end{array}$ & No & No & Abdominal pain & Mild & Yes & None \\
\hline 10 & 2nd, August 2020 & MOGAD & Yes (azathioprine) & No & $\begin{array}{l}\text { Headache and } \\
\text { fever }\end{array}$ & Mild & Yes & None \\
\hline 11 & 2nd, September 2020 & GBS & No (IVlg treatment) & No & URTI & Mild & Yes & None \\
\hline 12 & 2nd, September 2020 & MOGAD & $\begin{array}{l}\text { Yes (steroids, rituximab, and } \\
\text { IVlg replacement) }\end{array}$ & No & $\begin{array}{l}\text { URTI and } \\
\text { headache }\end{array}$ & Mild & Yes & None \\
\hline 13 & 2nd, September 2020 & $A C h R+M G$ & Yes (tacrolimus) & No & Fever + ageusia & Mild & Yes & None \\
\hline 14 & 2nd, January 2021 & OMS & No & No & Asymptomatic ${ }^{C}$ & Mild & Yes & None \\
\hline 15 & 2nd, January 2021 & $A C h R+M G$ & Yes (azathioprine) & No & URTI & Mild & Yes & None \\
\hline 16 & 2nd, January 2021 & MOGAD & Yes (rituximab) & No & Fever + myalgia & Mild & Yes & None \\
\hline 17 & 2nd, January 2021 & MS & Yes (natalizumab) & No & Myalgia & Mild & Yes & None \\
\hline
\end{tabular}

Abbreviations: AlJ = idiopathic juvenile arthritis; AChR = acetylcholine receptor; GBS = Guillain-Barré syndrome; IIH = idiopathic intracranial hypertension; IFN $\beta-1 \mathrm{a}$ = interferon beta-1a; IVIg = IV immunoglobulin; MG = myasthenia gravis; MOGAD = myelin oligodendrocyte glycoprotein-associated disease; MS = multiple sclerosis; OMS = opsoclonus myoclonus syndrome; URTI = upper respiratory tract infection.

${ }^{a}$ During the 1 st period of the study (March 14, 2020-June 21, 2020), suspected COVID-19 cases (without microbiological confirmation) were included due lower testing capacity for SARS-CoV-2 than clinical demand; during the 2 nd period of the study (June 22, 2021-March 31, 2021), only confirmed microbiological cases were included (see Methods).

${ }^{\mathrm{b}}$ Admission to hospital due to underlying neurologic disorder, no oxygen requirements.

cTested for SARS-CoV-2 due to positive family contact.

due to rituximab, 7 of them with treatment-induced dysgammaglobulinemia, and another 5 with lymphopenia $(2 / 5$ also showed leucopenia). Another 13 (36\%) patients without B-cell depletion had lymphopenia according to normal age range levels (median 700 lymphocytes/ $\mathrm{mm}^{3}$, IQR 375-1071 lymphocytes/ $\mathrm{mm}^{3}, 7 / 13$ also showed leucopenia); they included 9 patients treated with fingolimod, 1 with dimethyl fumarate, 1 with mycophenolate and cyclophosphamide, 1 with abatacept, and 1 with allogenic bone marrow transplantation.

In addition, we found that 16 patients (12 with immunosupressants and 4 without) of the 148 patients in which a blood white blood cell count was available, had neutropenia according normal range levels (median 1,100 neutrophil $/ \mathrm{mm}^{3}$, IQR $1,000-1,200$ neutrophil $/ \mathrm{mm}^{3}, 2 / 16$ showing leucopenia). No significant differences were found related to COVID-19 disease $(3 / 16$ vs $13 / 132 p=0.3838)$.

Among the rest of risk factors for COVID-19 infection (Table 1), the only ones that showed an association with confirmed or suspected COVID-19 infection were having cohabitants with confirmed or suspected COVID-19 ( $p<$ 0.001 ) and the presence of low levels of vitamin $\mathrm{D}$ in blood (median $20 \mathrm{ng} / \mathrm{dL}$ [IQR 16-29 ng/dL] vs $29 \mathrm{ng} / \mathrm{dL}$ [IQR $23-39 \mathrm{ng} / \mathrm{dL}], p=0.03935)$. This low level of vitamin $\mathrm{D}$ was even more prominent when only patients with confirmed COVID-19 were considered (median $17 \mathrm{ng} / \mathrm{dL}$ [IQR 14-19 $\mathrm{ng} / \mathrm{dL}$ ] vs median $29 \mathrm{ng} / \mathrm{dL}$ [IQR 23-39 ng/dL], $p=$ $0.0063)$. Having an essential worker as a cohabitant was not a risk factor for developing COVID-19 $(p=1)$. 
Children were able to return to face-to-face schooling in September 2020. In our cohort, 130 (85\%) restarted face-toface school attendance, $20(13 \%)$ maintained a remote only school format, and 3 (2\%) a mixed face-to-face/remote format. Forty-three (28\%) of 153 patients had a contact with a classmate with COVID-19, but only 1 became PCR positive. The type of school attendance (face to face or remote) or protective mask was not significantly different between children with or without COVID-19 (Table 1).

\section{COVID-19, Clinical Features, and Outcome}

Among the 153 patients, 17 (11\%) developed confirmed (11) or suspected (6) COVID-19. Clinical and demographic data are summarized in Table 2 . There were 16 patients with symptomatic COVID-19 infections; 11 (69\%) developed upper respiratory tract infection ( 5 with fever), 2 myalgia ( 1 with fever), 1 ageusia and fever, 1 headache and fever, and 1 abdominal pain (Table 2). All patients had mild COVID-19, and only 1 confirmed case required hospital admission due to exacerbation of the underlying neurologic disorder (opsoclonus myoclonus syndrome) but without requiring supplementary oxygen. All patients had complete recovery, and none developed a secondary autoimmune complication such as PIMS or persistent symptoms of COVID-19.

\section{Relapses of the Neuroimmunologic Disorder and COVID-19}

Thirty-one (20\%) patients developed relapses (25) or worsening (6) of their neurologic disorder during the entire study period. The frequency of neurologic relapses was similar in patients with and without COVID-19 (3/17, $18 \%$ vs $28 / 136$, $21 \%, p=1$ ) (Table 2).

\section{Changes in Health Care Delivery During the COVID-19 Pandemic}

One hundred and twenty (79\%) patients (61 with and 59 without immunosuppressive therapy) had changes in their hospital/clinic visit regimen (e.g., change from face-to-face to remote medical visits); 8 (5\%) had cancellation of diagnostic procedures such as MRI or blood tests; and 25 (16\%) did not have any changes. Parents of the 120 patients who were changed to remote visits were asked about their overall satisfaction with the implementation of this type of visits, and 70 (58\%) were very satisfied, 40 (33\%) satisfied, 9 (8\%) slightly satisfied, and $1(<1 \%)$ not satisfied.

\section{Discussion}

In this retrospective study of 153 pediatric patients with neuroimmunologic diseases, we did not observe differences in COVID-19 frequency or severity between patients treated or untreated with immunosuppressive therapies. Moreover, the severity of COVID-19 in our cohort was mild, and all patients had complete recovery. The true incidence of COVID-19 in children during the first year of the pandemic is unknown largely due to the lack of widespread testing.
However, some studies have reported frequencies between $5 \%$ and $11 \%$ in the general pediatric population, ${ }^{3-5}$ in line with the $11 \%$ found in our study. The observed good outcome in our patients supports preliminary data showing a low rate of severe COVID-19 in children treated with immunosuppressants ${ }^{3-5}$ and that outcomes are not different from that found in children untreated or treated with immunomodulatory therapies.

Some of the recommendations made at the beginning of the pandemic in patients with MS were to temporarily delay initiation or redosing of treatments that alter the lymphocyte number such as rituximab. ${ }^{6,7}$ However, although lymphopenia, B-cell depletion, and hypogammaglobulinemia were common effects of the drugs administered in our cohort, we did not observe an increased susceptibility to develop COVID-19 or poor outcome if infected. This contrasts with a report in adult patients with MS in which anti-CD20 drugs were associated with a significantly increased risk of developing severe COVID-19..$^{8}$ Although the results of our study could have been related to the increased protection of these patients from SARS-CoV-2 during the lockdown period, this is unlikely as the frequency of COVID-19 remained very low even after resuming face-to-face school attendance. Thus, it is possible that younger age is a protective factor that overcomes the risk engendered by immunosuppression.

Strikingly, although contact with a classmate with COVID-19 in school was high in our cohort (43 patients [28\%]), this did not confer a higher risk of becoming infected with SARS-CoV-2 even in the children receiving immunosuppressant drugs. These data and the high risk for COVID-19 infection in patients cohabitating with people who became infected with SARS-CoV-2 indicate that COVID-19 in children is frequently acquired at home. However, these findings must be interpreted with caution due to the small size of our cohort, and future studies with larger cohorts are needed to properly assess this risk.

Several reports in adults have described a possible link between vitamin $\mathrm{D}$ deficiency and risk of SARS-CoV-2 infection. ${ }^{9}$ Our data support this possible link in children as well, although further studies are required. Together, these data support the use of vitamin $\mathrm{D}$ supplementation in pediatric neuroimmunologic patients, especially during the COVID-19 pandemic., 9

Another issue not well addressed in previous reports was whether SARS-CoV-2 infection was associated with an increased risk of relapse or worsening of the underlying neuroimmunologic disorder. However, the frequency of relapses or worsening in patients with concurrent COVID-19 (18\%) in our study was not different from that observed in patients without COVID-19 (21\%).

Delayed diagnosis or provision of health care due to the COVID-19 pandemic was initially reported in some 
countries, with concerns as to whether this would have detrimental consequences. ${ }^{11}$ This led to the implementation of changes in the delivery of health care services, such as the use of telemedicine. ${ }^{12}$ Although we cannot quantify the consequences, in our study, only $6 \%$ of patients reported cancellation of a diagnostic procedure such as MRI or blood tests. Of the $78 \%$ of patients who received remote health care visits, almost all (91\%) were very satisfied or satisfied with this method of care.

This study has several limitations. First, not all Spanish pediatric neurologists answered the questionnaire, and some patients may have been missed. Second, the incidence of COVID-19 varied throughout Spain. However, to mitigate the bias this could have introduced, we included additional untreated (i.e., no immunosuppressants) patients from the same center where each study patient was enrolled. Third, confirmation of COVID-19 was very low during the first study period, but the frequency and prognosis were not different from those observed during the second study period that had no COVID-19 testing constraints, and fourth, there were patients in the immunosuppressant-treated and not treated groups who received IVIg. We cannot exclude that any of these patients benefited from a theoretical protective effect of the IVIg.

Despite these limitations, our data are reassuring as they show that COVID-19 is uncommon in immunosuppressed children with neuroimmunologic disorders and that patients who develop the infection usually have a favorable outcome. Although we cannot assure that immunosuppressive treatments are safe in all patients, our study shows an acceptable safety profile and supports the use of this type of therapy when needed.

\section{Acknowledgment}

The authors thank Dr. Josep Dalmau and Dr. Myrna Rosenfeld for critical review of the manuscript and the patients and families for their participation.

\section{Study Funding}

This work was supported in part by grants from Plan Nacional de $\mathrm{I}+\mathrm{D}+\mathrm{I}$ and cofinanced by the Instituto Salud Carlos III (ISCIII) - Subdirección General de Evaluación y Formento de la Investigación Sanitaria-and the Fondo Europeo de Desarrollo Regional (ISCIII-FEDER; PI18-00486 and PI21/00316 to TA); Pla estratègic de recerca i innovació en salut (PERIS), Departament de Salut, Generalitat de Catalunya (SLT006/17/ 00362, TA); Pablove Foundation (689368 to TA); Fundació Marató de TV3 (37/C/2021, TA and AS); Torrons Vicens Foundation (PFNR0144 to TA); 2021 Invest-AEP Grant to TA and 2019 Invest-AEP Support to GO from the Pediatric Spanish Society; and ECTRIMS Clinical Training Fellowship Exchange Programme 2020 to EF.

\section{Disclosure}

G. Olivé-Cirera, E. Fontseca, V. Cantarín-Extremera, M. Vázquez-López, M. Jiménez-Legido, V. González-Álvarez, J.
Ribeiro-Constante, A. Camacho-Salas, I. Martí, R. CanchoCandela, and M.J. Martínez-González report no disclosures. A. Saiz received compensation for consulting services and speaker honoraria from Bayer-Schering, Merck-Serono, Biogen Idec, Sanofi-Aventis, Teva, Novartis, and Roche. T. Armangue received speaking honoraria from Biogen and Novartis. Go to Neurology.org/NNfor full disclosures.

\section{Publication History}

Received by Neurology: Neuroimmunology \& Neuroinflammation June 1, 2021. Accepted in final form September 14, 2021.

\section{Appendix 1 Authors}

\begin{tabular}{lll}
\hline Name & Location & Contribution \\
\hline $\begin{array}{l}\text { Gemma } \\
\text { Olivé-Cirera, }\end{array}$ & $\begin{array}{l}\text { Neuroimmunology } \\
\text { Program, Institut } \\
\text { d'Investigacions } \\
\text { Biomèdiques August Pi i } \\
\text { Sunyer (IDIBAPS)-Hospital } \\
\text { Clinic, University of }\end{array}$ & $\begin{array}{l}\text { Drafting/revision of the } \\
\text { manuscript for content, } \\
\text { including medical writing for } \\
\text { content; major role in the } \\
\text { acquisition of data; and } \\
\text { analysis or interpretation of } \\
\text { data }\end{array}$ \\
& $\begin{array}{l}\text { Barcelona, Spain; Pediatric } \\
\text { Neurology Unit of Parc Taulí }\end{array}$ \\
& $\begin{array}{l}\text { Hospital of Sabadell } \\
\text { (Barcelona), Spain }\end{array}$ & \\
\hline Elianet & $\begin{array}{l}\text { Neuroimmunology } \\
\text { Fonseca, MD }\end{array}$ & $\begin{array}{l}\text { Drafting/revision of the } \\
\text { d'Investigacions }\end{array}$ \\
& $\begin{array}{l}\text { Biomèdiques August Pi i } \\
\text { Sunyer (IDIBAPS)-Hospital } \\
\text { including medical writing for } \\
\text { content }\end{array}$ & \\
& $\begin{array}{l}\text { Clinic, University of } \\
\text { Barcelona, Spain }\end{array}$ &
\end{tabular}

\begin{tabular}{lll}
\hline $\begin{array}{l}\text { Verónica } \\
\text { Cantarín- }\end{array}$ & $\begin{array}{l}\text { Pediatric Neurology Unit of } \\
\text { Hospital Infantil }\end{array}$ & $\begin{array}{l}\text { Major role in the acquisition } \\
\text { of data }\end{array}$ \\
$\begin{array}{l}\text { Extremera, } \\
\text { MD }\end{array}$ & $\begin{array}{l}\text { Universitario Niño Jesús } \\
\text { (Madrid), Spain }\end{array}$
\end{tabular}

María Pediatric Neurology Unit of Major role in the acquisition
Vázquez- Hospital Gregorio Marañón of data López, MD (Madrid), Spain

\begin{tabular}{lll}
\hline María & $\begin{array}{l}\text { Pediatric Neurology Unit of } \\
\text { Jiménez- }\end{array}$ & $\begin{array}{l}\text { Major role in the acquisition } \\
\text { of data }\end{array}$ \\
Legido, MD & $\begin{array}{l}\text { Universitario Niño Jesús } \\
\text { (Madrid), Spain }\end{array}$ &
\end{tabular}

\begin{tabular}{|c|c|c|}
\hline $\begin{array}{l}\text { Verónica } \\
\text { González- } \\
\text { Álvarez, MD }\end{array}$ & $\begin{array}{l}\text { Pediatric Neuroimmunology } \\
\text { Unit, Neurology Service, Sant } \\
\text { Joan de Déu (SJD) Children's } \\
\text { Hospital, University of } \\
\text { Barcelona, Spain }\end{array}$ & $\begin{array}{l}\text { Major role in the acquisition } \\
\text { of data }\end{array}$ \\
\hline $\begin{array}{l}\text { Juliana } \\
\text { Ribeiro- } \\
\text { Constante, } \\
\text { MD }\end{array}$ & $\begin{array}{l}\text { Pediatric Neuroimmunology } \\
\text { Unit, Neurology Service, Sant } \\
\text { Joan de Déu (SJD) Children's } \\
\text { Hospital, University of } \\
\text { Barcelona, Spain }\end{array}$ & $\begin{array}{l}\text { Major role in the acquisition } \\
\text { of data }\end{array}$ \\
\hline $\begin{array}{l}\text { Ana } \\
\text { Camacho- } \\
\text { Salas, MD }\end{array}$ & $\begin{array}{l}\text { Pediatric Neurology Unit of } \\
\text { Hospital Universitario } 12 \\
\text { de Octubre, Complutense } \\
\text { University of Madrid, } \\
\text { Spain }\end{array}$ & $\begin{array}{l}\text { Major role in the acquisition } \\
\text { of data }\end{array}$ \\
\hline
\end{tabular}

Itxaso Martí, Pediatric Neurology Unit of Major role in the acquisition $\begin{array}{lll}\text { Itxaso Marti, } & \text { Pediatric Neurology Unit of } & \text { Major role } \\ \text { MD } & \text { Hospital Universitario } & \text { of data }\end{array}$ Donostia (Guipuzcoa), Spain

\begin{tabular}{lll}
\hline Ramon & Pediatric Neurology Unit of \\
Cancho- & $\begin{array}{l}\text { Hospital Universitario Río } \\
\text { Candela, MD }\end{array}$ & $\begin{array}{l}\text { Mortega in the acquisition } \\
\text { Holladolid), Spain }\end{array}$
\end{tabular}


Appendix 1 (continued)

\begin{tabular}{|c|c|c|}
\hline Name & Location & Contribution \\
\hline $\begin{array}{l}\text { María Jesús } \\
\text { Martínez- } \\
\text { González, MD }\end{array}$ & $\begin{array}{l}\text { Pediatric Neurology Unit of } \\
\text { Cruces University Hospital, } \\
\text { Bilbao, Spain }\end{array}$ & $\begin{array}{l}\text { Major role in the acquisition } \\
\text { of data }\end{array}$ \\
\hline $\begin{array}{l}\text { Albert Saiz, } \\
\text { MD, PhD }\end{array}$ & $\begin{array}{l}\text { Neuroimmunology Program, } \\
\text { Institut d'Investigacions } \\
\text { Biomèdiques August Pi i } \\
\text { Sunyer (IDIBAPS)-Hospital } \\
\text { Clinic, University of Barcelona, } \\
\text { Spain }\end{array}$ & $\begin{array}{l}\text { Drafting/revision of the } \\
\text { manuscript for content, } \\
\text { including medical writing for } \\
\text { content }\end{array}$ \\
\hline $\begin{array}{l}\text { Thaís } \\
\text { Armangué, } \\
\text { MD, PhD }\end{array}$ & $\begin{array}{l}\text { Neuroimmunology Program, } \\
\text { Institut d'Investigacions } \\
\text { Biomèdiques August Pi i } \\
\text { Sunyer (IDIBAPS)-Hospital } \\
\text { Clinic, University of Barcelona, } \\
\text { Barcelona, Spain; Pediatric } \\
\text { Neuroimmunology Unit, } \\
\text { Neurology Service, Sant Joan } \\
\text { de Déu (SJD) Children's } \\
\text { Hospital, University of } \\
\text { Barcelona, Spain }\end{array}$ & $\begin{array}{l}\text { Drafting/revision of the } \\
\text { manuscript for content, } \\
\text { including medical writing for } \\
\text { content; major role in the } \\
\text { acquisition of data; study } \\
\text { concept or design; and } \\
\text { analysis or interpretation of } \\
\text { data }\end{array}$ \\
\hline
\end{tabular}

\section{Appendix 2 Coinvestigators}

Coinvestigators are listed at links.Iww.com/NXI/A655.

\section{References}

1. Hasan A, Mehmood N, Fergie J. Coronavirus disease (COVID-19) and pediatric patients: a review of epidemiology, symptomatology, laboratory and imaging results to guide the development of a management algorithm. Cureus. 2020;12(3): e7485.

2. Giovannoni G, Hawkes C, Lechner-Scott J, Levy M, Waubant E, Gold J. The COVID19 pandemic and the use of MS disease-modifying therapies. Mult Scler Relat Disord. 2020;39:102073.

3. Pollán M, Pérez-Gómez B, Pastor-Barriuso R, et al. Prevalence of SARS-CoV-2 in Spain (ENE-COVID): a nationwide, population-based seroepidemiological study. Lancet. 2020;396(10250):535-544.

4. Tagarro A, Epalza C, Santos M, et al. Screening and severity of Coronavirus disease 2019 (COVID-19) in children in Madrid, Spain. JAMA Pediatr. 2020; 174(10):1009.

5. Götzinger F, Santiago-García B, Noguera-Julián A, et al. COVID-19 in children and adolescents in Europe: a multinational, multicentre cohort study. Lancet Child Adolesc Health. 2020;4(9):653-661.

6. Berger JR, Brandstadter R, Bar-Or A. COVID-19 and MS disease-modifying therapies. Neurol Neuroimmunol Neuroinflammation. 2020;7(4):e761.

7. Korsukewitz C, Reddel SW, Bar-Or A, Wiendl H. Neurological immunotherapy in the era of COVID-19 - looking for consensus in the literature. Nat Rev Neurol. 2020; 16(9):493-505.

8. Sormani MP, De Rossi N, Schiavetti I, et al. Disease-Modifying therapies and Coronavirus disease 2019 severity in multiple sclerosis. Ann Neurol. 2021;89(4): 780-789.

9. Bergman P. The link between vitamin D and COVID-19: distinguishing facts from fiction. J Intern Med. 2021;289(1):131-133.

10. Banwell B, Bar-Or A, Arnold DL, et al. Clinical, environmental, and genetic determinants of multiple sclerosis in children with acute demyelination: a prospective national cohort study. Lancet Neurol. 2011;10(5):436-45.

11. Lazzerini M, Barbi E, Apicella A, Marchetti F, Cardinale F, Trobia G. Delayed access or provision of care in Italy resulting from fear of COVID-19. Lancet Child Adolesc Health. 2020;4(5):e10-e11.

12. Moccia M, Lanzillo R, Brescia Morra V, et al. Assessing disability and relapses in multiple sclerosis on tele-neurology. Neurol Sci. 2020;41(6):1369-1371. 


\section{Neurology \\ Neuroimmunology \& Neuroinflammation}

\section{Impact of COVID-19 in Immunosuppressed Children With Neuroimmunologic Disorders}

Gemma Olivé-Cirera, Elianet Fonseca, Verónica Cantarín-Extremera, et al.

Neurol Neuroimmunol Neuroinflamm 2022;9;

DOI 10.1212/NXI.0000000000001101

This information is current as of November 10, 2021

\section{Updated Information \& Services}

References

Subspecialty Collections

Permissions \& Licensing

Reprints including high resolution figures, can be found at: http://nn.neurology.org/content/9/1/e1101.full.html

This article cites 12 articles, 0 of which you can access for free at: http://nn.neurology.org/content/9/1/e1101.full.html\#\#ref-list-1

This article, along with others on similar topics, appears in the following collection(s):

All Demyelinating disease (CNS)

http://nn.neurology.org//cgi/collection/all_demyelinating_disease_cns

All Pediatric

http://nn.neurology.org//cgi/collection/all_pediatric

Autoimmune diseases

http://nn.neurology.org//cgi/collection/autoimmune_diseases

COVID-19

http://nn.neurology.org//cgi/collection/covid_19

Information about reproducing this article in parts (figures,tables) or in its entirety can be found online at:

http://nn.neurology.org/misc/about.xhtml\#permissions

Information about ordering reprints can be found online:

http://nn.neurology.org/misc/addir.xhtml\#reprintsus

Neurol Neuroimmunol Neuroinflamm is an official journal of the American Academy of Neurology.

Published since April 2014, it is an open-access, online-only, continuous publication journal. Copyright

Copyright $\odot 2021$ The Author(s). Published by Wolters Kluwer Health, Inc. on behalf of the American

Academy of Neurology.. All rights reserved. Online ISSN: 2332-7812.

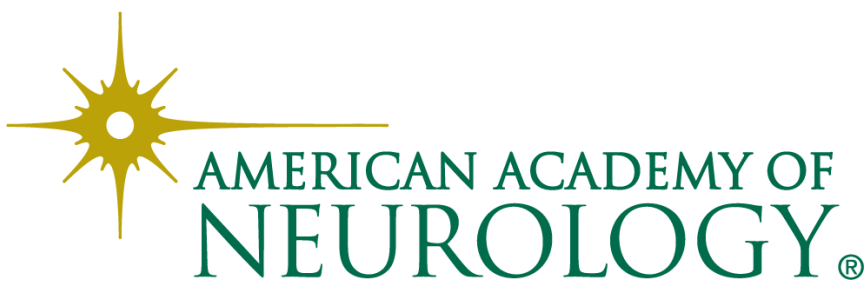

